\title{
Environmental Impact Assessment of Heavy Metals on African Catfish (Clarias gariepinus) of some Drains in Dakahlia Governorate, Egypt
}

\author{
Ahmed E. Hagras; Maie I. El-Gammal*; Abeer E. Abdrabouh and \\ Hanaa T. El-Bahnasy \\ Zoology Department, Faculty of Science, Mansoura University, Egypt \\ *Environmental Sciences Department, Faculty of Science, Damietta University, Egypt
}

\begin{abstract}
The contamination occurred to the aquatic ecosystem by heavy metals is caused by the discharge of massive amounts of domestic sewage as well as agricultural and industrial effluents. This contamination has been desired a major threat to the aquatic organisms. This study conducted seasonal variation of some heavy metals in the drainage water of random samples from three different drain sites in Dakahlia Governorate to measure the concentration and to assess the accumulation of heavy metals in gill and liver of African catfish (Clarias gariepinus) for seasons from the period 2015 to 2016. There were relative variations in heavy metals contents in the different study sites which can be ranked as follows: $\mathrm{Cu}>\mathrm{Ni}>\mathrm{Mn}>\mathrm{Co}>\mathrm{Cd}>\mathrm{Pb}>\mathrm{Fe}>\mathrm{Cr}$ $>\mathrm{Zn}$. Whereas the distribution of the heavy metals accumulated in the organs of $C$. gariepinus were detected in the following order: $\mathrm{Fe}>\mathrm{Ni}>\mathrm{Cd}>\mathrm{Pd}>\mathrm{Cr}>\mathrm{Mn}>\mathrm{Zn}>\mathrm{Cu}>\mathrm{Co}$. The correlation between heavy metal in water with condition factor values (Growth indicator) of fish is indicated on the ordination diagram produced by Canonical Correspondence Analysis (CCA) proved that, cadmium, chromium, cobalt, iron, zinc and lead were the most important water heavy metals affecting the condition factor values of $C$. gariepinus in different study sites at all seasons. Morphometric data were also given for each factor and variations were discussed. Keywords: Heavy Metals, Pollution, Catfish, Condition Factors, Accumulation Factors.
\end{abstract}

\section{Introduction}

Egyptian drains receive large quantities of partially treated or untreated domestic and industrial wastewater, as well as other human activities, which in turn affect on the aquatic fauna in this drains [1]. The African catfish namely, Clarias gariepinus is one of the most popular fish species dwelling River Nile and drainage canals in Egypt [2, 3]. Few studies have examined variation of fish health in different locations [4, 5]. Recently, an increasing number of studies have been shown how fish and contamination can interact with each other [6].

Heavy metals are referred to as 'conservative' pollutants because they are either not broken down at all, or they are broken down over such a long period of time that heavy metals essentially become permanent additions to the aquatic environment [7]. Most of heavy metals are characterized by being accumulated in tissues, and may lead to the poisoning of fish [8]. A heavy metal becomes toxic when a level is reached a degree where it damages the life functions of an organism. These pollutants have negative impacts, not only on water systems, but also on fish populations, their survival, growth and reproduction [9].

The main objective of this study is to determine the seasonal variation of the heavy metals concentrations in three selected drains in Dakahlia Governorate, and to assess the accumulation of some heavy metals in gill and liver of African catfish (Clarias gariepinus). Consequently, evaluation the effect of these heavy metals on fish has been demonstrated.

\section{Materials And Methods}

Water contamination is considered to be one of the most dangerous hazards affecting Egypt. Pollution in Dakahlia Governorate water systems has increased because of increases in population; several new projects, and other industrial activities in the cities.

\subsection{Sampling Strategy}

Water samples were collected for a year long period, seasonally (Starting from 2015 to 2016) from three sites; Aga, El-Manzala and El-Mansoura districts (Sites 1, 2, and 3), in Dakahlia Governorate (Table 1). The three sites were selected on the basis of their strategic positions that these sites include the variety sources of polluted drains water (Fig.1). 
Table (1): Drain Samples Sites Description

\begin{tabular}{|c|c|c|}
\hline No. of Site & locatios & Sites Description \\
\hline Site 1 & $\begin{array}{l}\text { Nawsa El-Gheet drain } \\
\text { (Aga District) }\end{array}$ & $\begin{array}{l}\text { It is located in southern of Dakahlia Governorate. This } \\
\text { district is related to agricultural drainage water. The site of } \\
\text { samples collection has coordinates: } 30^{\circ} 57^{\prime} 51^{\prime \prime} \mathrm{N}, 31^{\circ} 19^{\prime} \\
46^{\prime \prime} \mathrm{E}\end{array}$ \\
\hline Site 2 & $\begin{array}{l}\text { EL-Nasaima drain (El- } \\
\text { Manzala District) }\end{array}$ & $\begin{array}{l}\text { It is located in eastern of Dakahlia Governorate. It is } \\
\text { characterized by industrial activities, agricultural drainage } \\
\text { water and sewage water. The site of samples collection has } \\
\text { coordinates: } 31^{\circ} 13^{\prime} 42^{\prime \prime} \mathrm{N}, 31^{\circ} 38^{\prime} 33^{\prime \prime} \mathrm{E} \text {. }\end{array}$ \\
\hline Site 3 & $\begin{array}{l}\text { El-Mansoura } \\
\text { Mostagad drain } \\
\text { Mansoura District })\end{array}$ & $\begin{array}{l}\text { It is located near the center of Dakahlia Governorate. It is } \\
\text { characterized by industrial wastewater and agricultural } \\
\text { drainage water. The site of the samples collection has } \\
\text { coordinates: } 31^{\circ} 05^{\prime} 00^{\prime \prime} \mathrm{N}, 32^{\circ} 0^{\prime} 48^{\prime \prime} \mathrm{E} \text {. }\end{array}$ \\
\hline
\end{tabular}

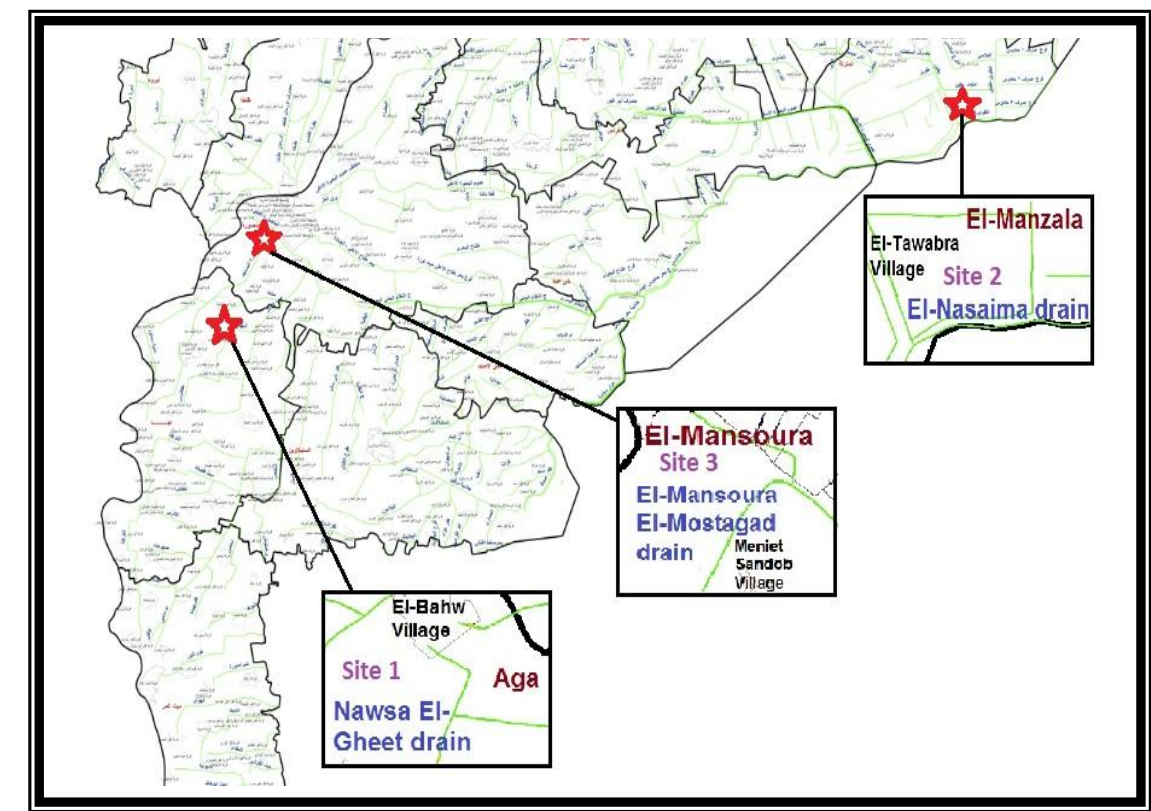

Fig. (1): Map of the study area and sampling sites in selective Districts of El-Dakahlia Governorate.

\subsection{Environmental Measurements}

\subsubsection{Sampling and Analysis of Heavy Metals in the Drain Water}

Heavy metals of drain samples were determined after digestion according to standard method (method for the examination of water and wastewater part 3000) [10].

The microelements; $\mathrm{Pb}, \mathrm{Cd}, \mathrm{Zn}, \mathrm{Co}, \mathrm{Cr}, \mathrm{Ni}, \mathrm{Mn}, \mathrm{Fe}$ and $\mathrm{Cu}$ were analyzed in the collected water samples seasonally using Buck Scientific Accusys 211 atomic absorption spectrophotometer according to [10].

\subsection{Exposure to Heavy Metals in the Drain Water}

\subsubsection{Sampling and Analysis of Heavy Metals for Experimental Fish}

A total of 60 specimens of the African catfish (Clarias gariepinus were collected from three study drain sites; 1, 2 and 3 in Dakahlia Governorate during seasonal intervals of the study period from 2015 to 2016. Control specimens of adult catfish, were collected from the River Nile at Kafr El-Tawila village (Talkha District, El-Dakahlia Governorate) and then were transported to Laboratory. The fish weight 200 to 350 grams were fed on a commercial pellet diet (3\% of body weight per day) and kept together in $100 \mathrm{~L}$ rectangular tanks containing tap water conductivity $2000 \mathrm{ls} \mathrm{cm}-1$; $\mathrm{pH} 7.5$; oxygen saturation 88 to $95 \%$; temperature 27 to $28^{\circ} \mathrm{C}$ for six months.

The fish weight and length were determined. The total length (L) of the fish was measured from the tip of the anterior part of the month to the caudal fin using meter rule calibrated in centimeters. Fish weight was measured after blot drying with a piece of clean hand towel. Weighing was done with a tabletop weighing balance in grams. 
All fish samples were stored frozen immediately after collection at $-10^{\circ} \mathrm{C}$ after that allowed thawing at room temperature. The fish samples after defrosting were dissected; liver and gill organs were taken with the help of a stainless steel stiletto. After dissection, all tissue samples were separately oven-dried to constant weight at $105 \pm 20^{\circ} \mathrm{C}$ and each ground to powder. The powdered samples were digested according to [11]. One gram of each sample was digested using 1.5.1 mixture of 70\% perchloric acid, concentrated nitric acid and concentrated sulphuric acid at $80 \pm 5^{\circ} \mathrm{C}$ in a fume chamber, till colorless liquid was obtained. Each digested sample was diluted to $20 \mathrm{ml}$ with de-ionized water and analyzed for heavy metals in a Buck Scientific Accusys 211 atomic absorption spectrophotometer. Values of heavy metals concentration were recorded in mg/l dry weight.

\subsubsection{Histological Examination}

A gill arch of the right side of each collected fish and Control gill specimens were photographed and analyzed by light microscopy (Nikon ${ }^{\circledR}$ Labophot) according to [12].

\subsection{Statistical Analysis}

The condition factor $(\mathrm{K})$ of the collected fish was estimated from the equation: $\mathrm{K}=100 \mathrm{~W} / \mathrm{L}^{3}$, where $\mathrm{K}=$ condition factor, $\mathrm{W}=$ weight of fish, $\mathrm{L}=$ length of fish $(\mathrm{cm})$ according to [13].

The accumulation factor (AF) of each heavy metal was calculated in gill and liver organs of C. gariepinus to give an indication about the accumulation efficiency for any particular pollutant in any fish organ according to [14].

The significance of differences in heavy metals concentrations in the study sites and in fish at different seasons were analyzed using cluster analysis [15]. Variations in condition factors in relation to heavy metal concentrations were also analyzed statistically using Canonical Corresponding Analysis (CCA) using CANOCO $[16,17]$.

\section{Results And Discussion}

\subsection{Analysis of Heavy Metals; Pb, Cd, Zn, Co, Cr, Ni, Mn, Fe and $\mathrm{Cu}$ in Drain Samples for Sites; 1, 2 and} 3.

The mean values and mean condition factors are given in Table (2). It is evident that the mean values of $\mathrm{Pb}, \mathrm{Cd}, \mathrm{Zn}, \mathrm{Co}, \mathrm{Cr}, \mathrm{Ni}, \mathrm{Mn}, \mathrm{Fe}$ and $\mathrm{Cu}$ were 0.002, 0.383, 0.064, 0.448, 0.079, 0.713, 0.601, 0.153 and 1.791 $\mathrm{mg} / \mathrm{L}$, respectively, for site 1 . However, the mean values of $\mathrm{Pb}, \mathrm{Cd}, \mathrm{Zn}, \mathrm{Co}, \mathrm{Cr}, \mathrm{Ni}, \mathrm{Mn}, \mathrm{Fe}$ and $\mathrm{Cu}$ for were $0.226,0.611,0.050,0.539,0.079,1.051,0.516,0.137$ and $1.092 \mathrm{mg} / \mathrm{L}$, respectively, site 2 . Whereas, the mean values of $\mathrm{Pb}, \mathrm{Cd}, \mathrm{Zn}, \mathrm{Co}, \mathrm{Cr}, \mathrm{Ni}, \mathrm{Mn}, \mathrm{Fe}$ and $\mathrm{Cu}$ were $0.529,0.131,0.048,0.117,0.113,0.222,0.727,0.115$ and $0.526 \mathrm{mg} / \mathrm{L}$, respectively, for site 3 .

In a correlation between heavy metals, of sites; 1,2 and 3, that was ranked following the orders:

For site $1: \mathrm{Cu}>\mathrm{Ni}>\mathrm{Mn}>\mathrm{Co}>\mathrm{Cd}>\mathrm{Fe}>\mathrm{Cr}>\mathrm{Zn}>\mathrm{Pd}$.

For site 2: $\mathrm{Cu}>\mathrm{Ni}>\mathrm{Cd}>\mathrm{Co}>\mathrm{Mn}>\mathrm{Pd}>\mathrm{Fe}>\mathrm{Cr}>\mathrm{Zn}$.

For site $3 \mathrm{:} \mathrm{Mn}>\mathrm{Pd}>\mathrm{Cu}>\mathrm{Ni}>\mathrm{Cd}>\mathrm{Co}>\mathrm{Fe}>\mathrm{Cr}>\mathrm{Zn}$.

According to the above mentioned results, the following conclusions must be detailed: the highest mean values of $\mathrm{Pd}$ and $\mathrm{Mn}$ were 1.035 and $0.993 \mathrm{mg} / \mathrm{L}$, respectively, recorded for site 3 . Whereas, the highest mean values of $\mathrm{Cd}, \mathrm{Zn}, \mathrm{Co}, \mathrm{Ni}, \mathrm{Fe}$ and $\mathrm{Cu}$ were 1 0.988, 0.143, 1.423, 0.074, 0.233 and $2.766 \mathrm{mg} / \mathrm{L}$, respectively, recorded for site1. The highest mean values of $\mathrm{Cr}$ were $0.213 \mathrm{mg} / \mathrm{L}$ for site 2 . These high concentrations may be attributed to the high amounts of sewage, industrial and agricultural effluents discharging into the drains for these study sites.

However, The lowest mean values of $\mathrm{Pd}, \mathrm{Mn}, \mathrm{Fe}$ and $\mathrm{Cu}$ were $0.001,0.294,0.003$ and $0.624 \mathrm{mg} / \mathrm{L}$, respectively, recorded in the drain of site 2, while the lowest values of $\mathrm{Cd}$ and $\mathrm{Zn}$ were 0.006 and $0.003 \mathrm{mg} / \mathrm{L}$, respectively, recorded in drain of site 1 . The lowest values of $\mathrm{Co}, \mathrm{Cr}$ and $\mathrm{Ni}$ were $0.002,0.002$ and $0.008, \mathrm{mg} / \mathrm{L}$, respectively, recorded in drain of site 3.

It was noticed that, $\mathrm{Cu}$ concentrations were non-detectable in all study drain sites during summer and were also non-detectable for drain of site 3 in spring and autumn. The permissible limits for heavy metals in water set by $[18,19]$ (Table 2).

The main sources of aquatic contamination are pesticides, drainage and waste waters from agricultural run- off, industrial effluents and domestic sewage [20]. Pollution of the aquatic ecosystem by heavy metals can be confirmed in the water, organisms [22]. Heavy metals are among the effective contaminants which have drastic environmental effect on all organisms [21].

The condition factor value of $C$. gariepinus, was the maximum value of 1.66 in El-Manzala during autumn, while the minimum condition factor value of $C$. gariepinus was detected in El-Manzala during summer of value 0.53 with a mean condition factor value of 0.86 (Table 2). 
In general the condition factor value of $C$. gariepinus in El-Manzala was higher than in El-Mansoura, whereas, the lowest values of condition factor were detected in Aga. According to the mean values of estimated heavy metals concentrations, it can be ranked as following: $\mathrm{Cu}>\mathrm{Ni}>\mathrm{Mn}>\mathrm{Co}>\mathrm{Cd}>\mathrm{Pb}>\mathrm{Fe}>\mathrm{Cr}>\mathrm{Zn}$.

In natural aquatic environments, metals occur in low concentrations, normally at nanograms to micrograms per liter level. In recent times, the occurrence of metal contaminants in excess of natural loads has become a problem of increasing concern. This occurs as a result of the rapid increase of population, increased urbanization and expansion of industrial activities, exploration and exploitation of natural resources, extension of irrigation and other modern agricultural practices, as well as the lack of environmental regulations [23]. In this study the values of heavy metals recorded in water samples were generally high when compared with the limit of chronic reference values suggested by [18] and [24] and the Egyptian laws [25, 26].

Table (2): Seasonal variations of condition factor of $C$. gariepinus and heavy metals concentration in water samples and the permissible limits for heavy metals in water set by WHO (1985 \& 2005).

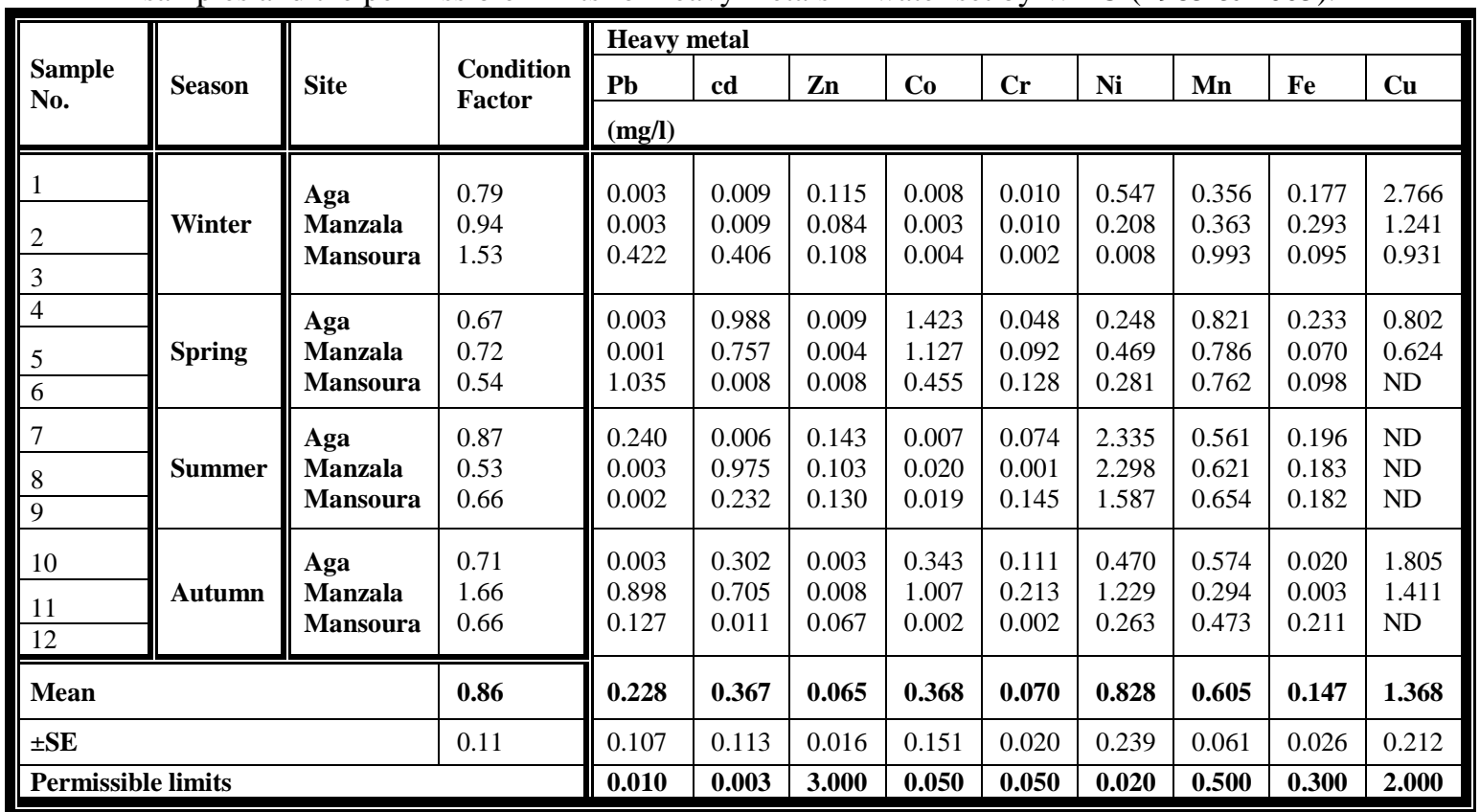

\subsection{Accumulation of Heavy Metals in Fish Organs}

In the present study, the heavy metals accumulated in gill of $C$. gariepinus, the highest mean concentration values of $\mathrm{Pd}, \mathrm{Cd}, \mathrm{Zn}$ and $\mathrm{Cr}$ were $3.607,6.212,1.648$ and $2.683 \mu \mathrm{g} / \mathrm{g}$ dry wt, respectively, recorded in the drain of site 1 , while the highest mean concentration values of $\mathrm{Co}, \mathrm{Ni}, \mathrm{Fe}$ and $\mathrm{Cu}$ were 7.752 , 9.933, 14.578 and $2.374 \mu \mathrm{g} / \mathrm{g}$ dry $\mathrm{wt}$, respectively, recorded in the drain of site 2 . The highest mean concentration values of $\mathrm{Mn}$ were $2.759 \mu \mathrm{g} / \mathrm{g}$ dry wt, recorded in the drain of site 3 . According to [27], the maximum accumulation heavy metals was detected in gills and this is may be due to their high capacity to accumulate heavy metals brought by blood from other tissues including liver and muscles of the body and induce the production of the metal binding protein, metallothionein, that is believed to have a crucial role against the heavy metals by binding them [28]. The lowest mean concentration values of $\mathrm{Pd}, \mathrm{Cr}$ and $\mathrm{Mn}$ were $0.003,0.041$ and $0.007 \mu \mathrm{g} / \mathrm{g}$ dry $\mathrm{wt}$, respectively, recorded in the drain of site 1 , while the lowest concentration values of $\mathrm{Cd}, \mathrm{Zn}, \mathrm{Co}, \mathrm{Ni}, \mathrm{Fe}$ and $\mathrm{Cu}$ were $0.008,0.520,0.003,0.009,0.003$ and $0.009 \mu \mathrm{g} / \mathrm{g}$ dry wt, respectively, recorded in the drain of site 2 . The concentrations of $\mathrm{Pd}, \mathrm{Cd}, \mathrm{Zn}, \mathrm{Co}, \mathrm{Cr}, \mathrm{Ni}, \mathrm{Mn}, \mathrm{Fe}$ and $\mathrm{Cu}$ for the gill of the control sample of $C$. gariepinus were $0.002,0.008,0.831,0.004,0.216,0.013,0.218,0.492$ and $0.002 \mu \mathrm{g} / \mathrm{g}$ dry wt, respectively, (Table 3). 
Table (3): Seasonal variations of the heavy metals concentration in gill of $C$. gariepinus, collected from the study sites with control sample and mean of accumulation factor.

\begin{tabular}{|c|c|c|c|c|c|c|c|c|c|c|c|}
\hline \multirow{3}{*}{$\begin{array}{l}\text { Sample } \\
\text { No. }\end{array}$} & \multirow{3}{*}{ Season } & \multirow{3}{*}{ Site } & \multicolumn{9}{|c|}{ Heavy metal } \\
\hline & & & $\mathbf{P b}$ & cd & Zn & Co & $\mathrm{Cr}$ & $\mathrm{Ni}$ & Mn & $\mathbf{F e}$ & $\mathrm{Cu}$ \\
\hline & & & \multicolumn{9}{|l|}{$(\mathrm{mg} / \mathrm{l})$} \\
\hline 1 & \multirow{3}{*}{ Winter } & \multirow{3}{*}{$\begin{array}{l}\text { Aga } \\
\text { Manzala } \\
\text { Mansoura }\end{array}$} & \multirow{3}{*}{$\begin{array}{l}0.003 \\
3.084 \\
0.855\end{array}$} & \multirow{3}{*}{$\begin{array}{l}0.549 \\
0.163 \\
2.679\end{array}$} & \multirow{3}{*}{$\begin{array}{l}1.056 \\
1.254 \\
1.273\end{array}$} & \multirow{3}{*}{$\begin{array}{l}0.008 \\
0.013 \\
4.780\end{array}$} & \multirow{3}{*}{$\begin{array}{l}0.954 \\
1.579 \\
2.301\end{array}$} & \multirow{3}{*}{$\begin{array}{l}5.116 \\
0.009 \\
1.933\end{array}$} & \multirow{3}{*}{$\begin{array}{l}0.014 \\
0.993 \\
0.010\end{array}$} & \multirow{3}{*}{$\begin{array}{l}0.009 \\
14.578 \\
1.717\end{array}$} & \multirow{3}{*}{$\begin{array}{l}0.157 \\
0.009 \\
0.260\end{array}$} \\
\hline 2 & & & & & & & & & & & \\
\hline 3 & & & & & & & & & & & \\
\hline 4 & \multirow{3}{*}{ Spring } & \multirow{3}{*}{$\begin{array}{l}\text { Aga } \\
\text { Manzala } \\
\text { Mansoura }\end{array}$} & \multirow{3}{*}{$\begin{array}{l}0.062 \\
2.725 \\
2.677\end{array}$} & \multirow{3}{*}{$\begin{array}{l}0.785 \\
3.168 \\
2.574\end{array}$} & \multirow{3}{*}{$\begin{array}{l}0.926 \\
0.912 \\
1.221\end{array}$} & \multirow{3}{*}{$\begin{array}{l}0.005 \\
0.003 \\
0.020\end{array}$} & \multirow{3}{*}{$\begin{array}{l}1.470 \\
1.870 \\
1.560\end{array}$} & \multirow{3}{*}{$\begin{array}{l}4.060 \\
0.014 \\
0.878\end{array}$} & \multirow{3}{*}{$\begin{array}{l}0.007 \\
1.987 \\
2.759\end{array}$} & \multirow{3}{*}{$\begin{array}{l}9.457 \\
0.334 \\
13.821\end{array}$} & \multirow{3}{*}{$\begin{array}{l}1.602 \\
1.432 \\
0.923\end{array}$} \\
\hline 5 & & & & & & & & & & & \\
\hline 6 & & & & & & & & & & & \\
\hline 7 & \multirow{3}{*}{ Summer } & \multirow{3}{*}{$\begin{array}{l}\text { Aga } \\
\text { Manzala } \\
\text { Mansoura }\end{array}$} & \multirow{3}{*}{$\begin{array}{l}0.221 \\
0.016 \\
0.019\end{array}$} & \multirow{3}{*}{$\begin{array}{l}6.212 \\
0.023 \\
1.608\end{array}$} & \multirow{3}{*}{$\begin{array}{l}1.648 \\
0.928 \\
1.313\end{array}$} & \multirow{3}{*}{$\begin{array}{l}0.013 \\
2.355 \\
0.016\end{array}$} & & 0.504 & 2.269 & 4.637 & 0.743 \\
\hline 8 & & & & & & & 0.108 & 0.011 & 1.548 & 0.006 & 2.374 \\
\hline$\frac{0}{9}$ & & & & & & & 0.517 & 4.561 & 1.228 & 10.635 & 0.107 \\
\hline 10 & & Aga & 3.607 & 4.262 & 0.994 & 0.016 & 2.683 & 0.725 & 2.006 & 4.409 & 0.556 \\
\hline 11 & Autumn & Manzala & 0.010 & 0.008 & 0.520 & 7.752 & 2.250 & 9.933 & 0.009 & 0.003 & 0.858 \\
\hline $\begin{array}{l}11 \\
12\end{array}$ & & Mansoura & 2.107 & 3.349 & 1.493 & 0.023 & 1.041 & 0.860 & 0.688 & 1.409 & 0.612 \\
\hline Mean & & & 1.282 & 2.115 & 1.128 & 1.250 & 1.364 & 2.384 & 1.126 & 5.084 & 0.803 \\
\hline$\pm \mathrm{SE}$ & & & 0.414 & 0.562 & 0.087 & 0.727 & 0.247 & 0.870 & 0.287 & 1.609 & 0.203 \\
\hline Mean of & ntrol samp & & 0.002 & 0.008 & 0.831 & 0.004 & 0.216 & 0.013 & 0.218 & 0.492 & 0.002 \\
\hline & & \pm SE & 0.001 & 0.003 & 0.081 & 0.001 & 0.099 & 0.006 & 0.093 & 0.032 & 0.001 \\
\hline Mean of & umulation & tor & 5.617 & 5.760 & 17.311 & 3.397 & 19.589 & 2.878 & 1.863 & 34.652 & 0.587 \\
\hline
\end{tabular}

Concerning the heavy metals accumulated in liver of $C$. gariepinus, the highest mean concentration values of $\mathrm{Pd}$ and Fe were 6.322 and $36.633 \mu \mathrm{g} / \mathrm{g}$ dry wt, respectively, recorded in the drain of site 2, while the highest mean concentration values of $\mathrm{Cd}, \mathrm{Co}, \mathrm{Cr}$, Ni and $\mathrm{Mn}$ were 6.365, 0.692, 2.976, 4.215, and 2.394 $\mu \mathrm{g} / \mathrm{g}$ dry wt, respectively, recorded in the drain of site 1 . The highest mean concentration values of $\mathrm{Zn}$ and $\mathrm{Cu}$ were 1.897 and $2.295 \mu \mathrm{g} / \mathrm{g}$ dry wt, respectively, recorded in the drain of site 3 . The amount of contaminants in the liver of fish is directly proportional to the level of pollution in the aquatic environment by heavy metals was reported [29]. The lowest mean concentration values of $\mathrm{Pd}, \mathrm{Cd}, \mathrm{Zn}, \mathrm{Cr} \mathrm{Mn}$ and Fe were 0.014, 0.013, 0.619, $0.011,0.011$ and $0.006 \mu \mathrm{g} / \mathrm{g}$ dry wt, respectively, recorded in the drain of site 1 , while the lowest concentration values of $\mathrm{Co}$ and $\mathrm{Ni}$ were 0.005 and $0.002 \mu \mathrm{g} / \mathrm{g}$ dry wt, respectively, recorded in the drain of site 2 . The lowest concentration values of $\mathrm{Cu}$ were $0.252 \mathrm{mg} / \mathrm{L}$ recorded in the drain of site 3 .However, The concentrations of $\mathrm{Pd}$, $\mathrm{Cd}, \mathrm{Zn}, \mathrm{Co}, \mathrm{Cr}, \mathrm{Ni}, \mathrm{Mn}, \mathrm{Fe}$ and $\mathrm{Cu}$ for the liver of the control sample of C. gariepinus were 0.069, 0.018, 0.437, $0.003,0.140,0.013,0.260,0.458$ and $0.075 \mu \mathrm{g} / \mathrm{g}$ dry wt, respectively (Table 3 ). Heavy metals can alter species organ compositions and interspecific interaction [30, 31].

Table (4): Seasonal variations of the heavy metals concentration in liver of $C$. gariepinus, control sample, and the mean of accumulation factor.

\begin{tabular}{|c|c|c|c|c|c|c|c|c|c|c|c|}
\hline \multirow{3}{*}{$\begin{array}{l}\text { Sample } \\
\text { No. }\end{array}$} & \multirow{3}{*}{ Season } & \multirow{3}{*}{ Site } & \multicolumn{9}{|c|}{ Heavy metal } \\
\hline & & & $\mathbf{P b}$ & cd & Zn & Co & $\mathrm{Cr}$ & $\mathbf{N i}$ & Mn & $\mathrm{Fe}$ & $\mathrm{Cu}$ \\
\hline & & & \multicolumn{9}{|c|}{$(\mathrm{mg} / \mathrm{l})$} \\
\hline 1 & \multirow{3}{*}{ Winter } & \multirow{3}{*}{$\begin{array}{l}\text { Aga } \\
\text { Manzala } \\
\text { Mansoura }\end{array}$} & \multirow{3}{*}{$\begin{array}{l}0.014 \\
2.292 \\
0.236\end{array}$} & \multirow{3}{*}{$\begin{array}{l}0.013 \\
0.163 \\
0.765\end{array}$} & \multirow{3}{*}{$\begin{array}{l}1.562 \\
1.876 \\
1.897\end{array}$} & \multirow{3}{*}{$\begin{array}{l}0.009 \\
0.005 \\
0.014\end{array}$} & \multirow{3}{*}{$\begin{array}{l}1.165 \\
1.765 \\
2.291\end{array}$} & \multirow{3}{*}{$\begin{array}{l}2.620 \\
1.771 \\
0.008\end{array}$} & \multirow{3}{*}{$\begin{array}{l}0.011 \\
0.292 \\
0.651\end{array}$} & \multirow{3}{*}{$\begin{array}{l}13.751 \\
18.796 \\
0.007\end{array}$} & \multirow{3}{*}{$\begin{array}{l}0.807 \\
0.510 \\
2.295\end{array}$} \\
\hline 2 & & & & & & & & & & & \\
\hline 3 & & & & & & & & & & & \\
\hline 4 & \multirow{3}{*}{ Spring } & \multirow{3}{*}{$\begin{array}{l}\text { Aga } \\
\text { Manzala } \\
\text { Mansoura }\end{array}$} & \multirow{3}{*}{$\begin{array}{l}0.665 \\
4.356 \\
3.292\end{array}$} & \multirow{3}{*}{$\begin{array}{l}0.777 \\
2.080 \\
3.441\end{array}$} & \multirow{3}{*}{$\begin{array}{l}0.915 \\
1.122 \\
0.791\end{array}$} & \multirow{3}{*}{$\begin{array}{l}0.692 \\
0.394 \\
0.016\end{array}$} & \multirow{3}{*}{$\begin{array}{l}1.408 \\
2.209 \\
1.738\end{array}$} & \multirow{3}{*}{$\begin{array}{l}3.080 \\
0.011 \\
0.024\end{array}$} & \multirow{3}{*}{$\begin{array}{l}1.392 \\
2.018 \\
2.266\end{array}$} & \multirow{3}{*}{$\begin{array}{l}7.977 \\
20.965 \\
9.070 \\
\end{array}$} & \multirow{3}{*}{$\begin{array}{l}1.448 \\
1.000 \\
0.164\end{array}$} \\
\hline 5 & & & & & & & & & & & \\
\hline 6 & & & & & & & & & & & \\
\hline 7 & \multirow{3}{*}{ Summer } & \multirow{3}{*}{$\begin{array}{l}\text { Aga } \\
\text { Manzala } \\
\text { Mansoura }\end{array}$} & \multirow{3}{*}{$\begin{array}{l}1.100 \\
5.315 \\
1.485\end{array}$} & \multirow{3}{*}{$\begin{array}{l}0.798 \\
0.240 \\
1.343\end{array}$} & \multirow{3}{*}{$\begin{array}{l}1.192 \\
1.424 \\
0.823\end{array}$} & \multirow{3}{*}{$\begin{array}{l}0.004 \\
0.350 \\
0.013\end{array}$} & \multirow{3}{*}{$\begin{array}{l}0.011 \\
0.019 \\
0.435\end{array}$} & \multirow{3}{*}{$\begin{array}{l}0.352 \\
0.002 \\
0.140\end{array}$} & 1.388 & 27.204 & 0.358 \\
\hline 8 & & & & & & & & & 1.505 & 36.633 & 1.580 \\
\hline 9 & & & & & & & & & 0.025 & 3.643 & 0.252 \\
\hline 10 & & Aga & 3.140 & 6.365 & 0.619 & 0.373 & 2.976 & 4.215 & 2.394 & 0.006 & 1.101 \\
\hline 11 & Autumn & Manzala & 6.322 & 1.115 & 1.244 & 0.600 & 2.532 & 4.121 & 0.025 & 28.563 & 0.356 \\
\hline$\frac{11}{12}$ & & Mansoura & 2.506 & 0.759 & 1.287 & 0.004 & 1.609 & 1.806 & 1.198 & 7.153 & 0.973 \\
\hline Mean & & & 2.560 & 1.488 & 1.229 & 0.206 & 1.513 & 1.513 & 1.097 & 14.481 & 0.904 \\
\hline$\pm \mathrm{SE}$ & & & 0.582 & 0.520 & 0.119 & 0.075 & 0.278 & 0.478 & 0.255 & 3.453 & 0.184 \\
\hline
\end{tabular}




\begin{tabular}{|c|c|c|c|c|c|c|c|c|c|}
\hline Mean of control sample & $\begin{array}{l}\mathbf{0 . 0 6 9} \\
0.004\end{array}$ & $\begin{array}{l}\mathbf{0 . 0 1 8} \\
0.001\end{array}$ & $\begin{array}{l}\mathbf{0 . 4 3 7} \\
0.004\end{array}$ & $\begin{array}{l}\mathbf{0 . 0 0 3} \\
0.002\end{array}$ & $\begin{array}{l}\mathbf{0 . 1 4 0} \\
0.018\end{array}$ & $\begin{array}{l}\mathbf{0 . 0 1 3} \\
0.002\end{array}$ & $\begin{array}{l}\mathbf{0 . 2 6 0} \\
0.120\end{array}$ & $\begin{array}{l}\mathbf{0 . 4 5 8} \\
0.135\end{array}$ & $\begin{array}{l}\mathbf{0 . 0 7 5} \\
0.005\end{array}$ \\
\hline Mean of accumulation factor & 11.216 & 4.054 & 18.866 & 0.560 & 21.725 & 1.826 & 1.814 & 98.692 & 0.660 \\
\hline
\end{tabular}

Tables ( 3 and 4) show the heavy metals concentration accumulated in gill and liver and the accumulation factor of heavy metals in these organs of C. gariepinus, in the three study sites during four seasons. It has been found that the liver attained the highest accumulation values of heavy metals followed by the gills. These findings agree with the results of $[32,33]$ and $[34]$ who found that the distribution of the heavy metals in the investigated organs was shown to follow the order: liver $>$ gills $>$ muscles.

The present results showed that the heavy metals concentrations in fish organs (gills and liver) of $C$. gariepinus were relatively associated with metal content of water samples in the three drains and detected in the following order: $\mathrm{Fe}>\mathrm{Ni}>\mathrm{Cd}>\mathrm{Pd}>\mathrm{Cr}>\mathrm{Mn}>\mathrm{Zn}>\mathrm{Cu}>\mathrm{Co}$. Study by [25] on water heavy metals of ElManzala and Burullos lakes and Oreochromis niloticus organs (muscle, gill and liver) found that the detected heavy metals in fish organs were in the following rank: $\mathrm{Fe}>\mathrm{Zn}>\mathrm{Cu}>\mathrm{Mn}>\mathrm{Pb}>\mathrm{Cd}$. A significant relationship between heavy metals concentrations in aquatic organisms and water were observed by [36] and [37]. The present results indicated that the heavy metals concentrations in fish organs in El-Manzala were higher than in both of Aga and El-Mansoura drain sites.

Variations in the levels of heavy metals among the fish organs may be explained mainly in terms of the chemical forms of the elements and their concentrations in the local ecosystem, microbiological activity and differences in fish size. Also, different feeding habits of fish also contributes to the variation in metal accumulation. A direct relationship between the trophic level heavy metals accumulation in the fish, reported that omnivorous fish as $C$. gariepinus, had higher levels of heavy metals in its organs than carnivorous and planktivorus [38]. The difference in the accumulation of heavy metals in various organs of fish may be related to the proximity of the organ tissues to absorb the metals, i.e., the quantity present in water, sediment, plankton, age and type of the fish and presence of ligands in the organ tissues having an affinity to the metal and/or to the role of the tissue in the detoxification process [39]. The gills and liver were chosen as important organs for assessing metals accumulation. The high levels of heavy metals in the gills reflect the concentrations of metals in the waters, where the fish live, while the concentrations of metals in liver represent storage of metals in the fish body [40, 34].

The obtained results in the present study showed that, the highest concentrations of Fe and Pd were accumulated in liver. $\mathrm{Cd}$ and $\mathrm{Cu}$ concentration increased in fish liver collected from water near the agricultural areas [41]. The high accumulation of heavy metals in liver and gills affect on amount of the proteins which are synthesized in liver and gills organs when fishes were exposed to heavy metals and detoxify them [42]. These proteins are thought to have an important role in protecting them from damage by heavy metals. Gills are also the site in which, directly exposed to the ambient conditions and are also known for their excretory functions even for some metals like zinc [43]. Moreover, another results observations were reported by other authors carried out with various fish species $[44,45]$.

\subsection{Accumulation factor percentage of heavy metals in different organs}

As can be seen in Figs. 1 and 2. In comparing of accumulation factor \% of heavy metals $(\mathrm{Pb}, \mathrm{Cd}, \mathrm{Zn}$, $\mathrm{Co}, \mathrm{Cr}, \mathrm{Ni}, \mathrm{Mn}, \mathrm{Fe}$ and $\mathrm{Cu}$ ) in different organs (gills and liver) of C. gariepinus, it is clear that $\mathrm{Fe}$ has the highest ability to accumulate in gills of C. gariepinus, as its accumulation factor \% of Fe was $30.75 \%$ followed by $\mathrm{Ni}$ which record accumulation $14.41 \%$. Whereas, accumulation factor $\%$ of $\mathrm{Cd}, \mathrm{Cr}, \mathrm{Pd}, \mathrm{Co}, \mathrm{Zn}$ and $\mathrm{Mn}$ were $12.79,8.25,7.75,7.56,6.8$ and $6.81 \%$, respectively. However, $\mathrm{Cu}(4.85 \%)$ showed the lowest ability for accumulation \% in gills of C. gariepinus (Fig. 2).

Concerning liver of $C$. gariepinus $\mathrm{Fe}$ has the highest ability to accumulate in liver of $C$. gariepinus, as accumulation factor $\%$ of Fe was 57.94\% followed by Pd which record accumulation factor $10.24 \%$, Whereas, accumulation factor \% of $\mathrm{Cr}, \mathrm{Ni}, \mathrm{Cd}, \mathrm{Zn}, \mathrm{Mn}$ and $\mathrm{Cu}(6.05,6.05,6.95,4.92,4.39$ and 3.62 ). However, Co $(0.82 \%)$ showed the lowest ability for accumulation percent in liver of C. gariepinus (Fig. 3). 


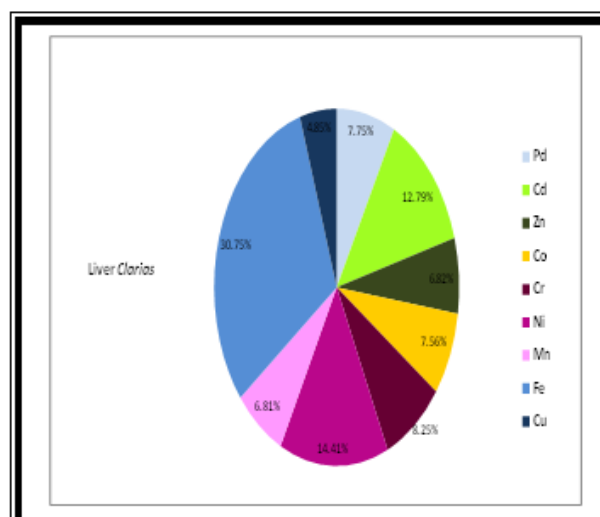

Fig. (2): Accumulation factor $\%$ of different heavy metals in gills of $C$. gariepinus.

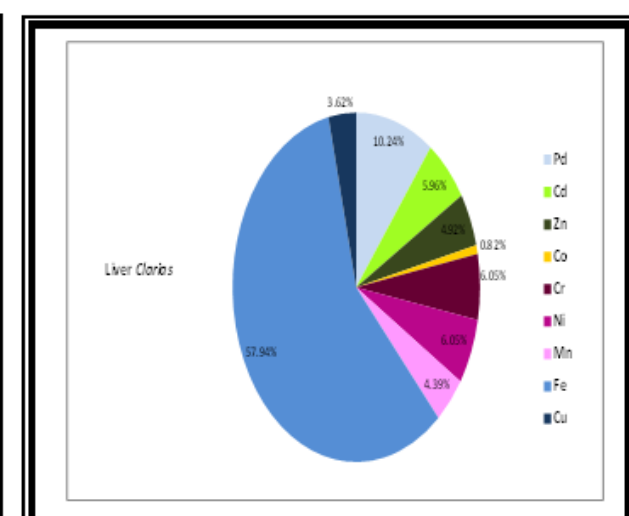

Fig. (3): Accumulation factor \% of different heavy metals in liver of $C$. gariepinus

The microscopic photograph structures of gills from control $C$. gariepinus and specimens were collected form sites 1, 2 and 3 were shown in Figs. 4, 5, 6 and 7, respectively. The pathological changes in the gills of catfish $C$. gariepinus may be due to a reaction to heavy metal toxicants intake or an adaptive response to prevent the entry of the pollutants through the gill surface. Several investigators had approved histopathological changes in the gills of different fish species exposed to heavy metals [46]. Since gills are the respiratory and osmoregulatory organ of the fish, the histopathological changes in the gills might impair the respiratory function of the gills by reducing respiratory surface area, resulted in hypoxia, respiratory failure problems [47; 48] and this badly affects the physiology and may be lead to the death of fish [49]. In the present study, it is noticed a wide spectrum of histopathologies was revealed in the gills of $C$. gariepinus fish collected from the selected drains. The present results are in agreement with others observed in fish under the influence of different pollutants $[50 ; 51]$. In this point, [52; 53] observed hyperplasia of the epithelial cells, fusion of secondary lamellae, lifting of the lamellar epithelium, hyperplasia of mucous cells, edema in gill filaments and secondary lamellae, necrosis of epithelial cells and blood congestion in the gills of fish inhabited water polluted by industrial, domestic and agricultural wastes. These results in the increase of the distance between the external environment and the blood and thus serve as a barrier to the entrance of contaminants [54].
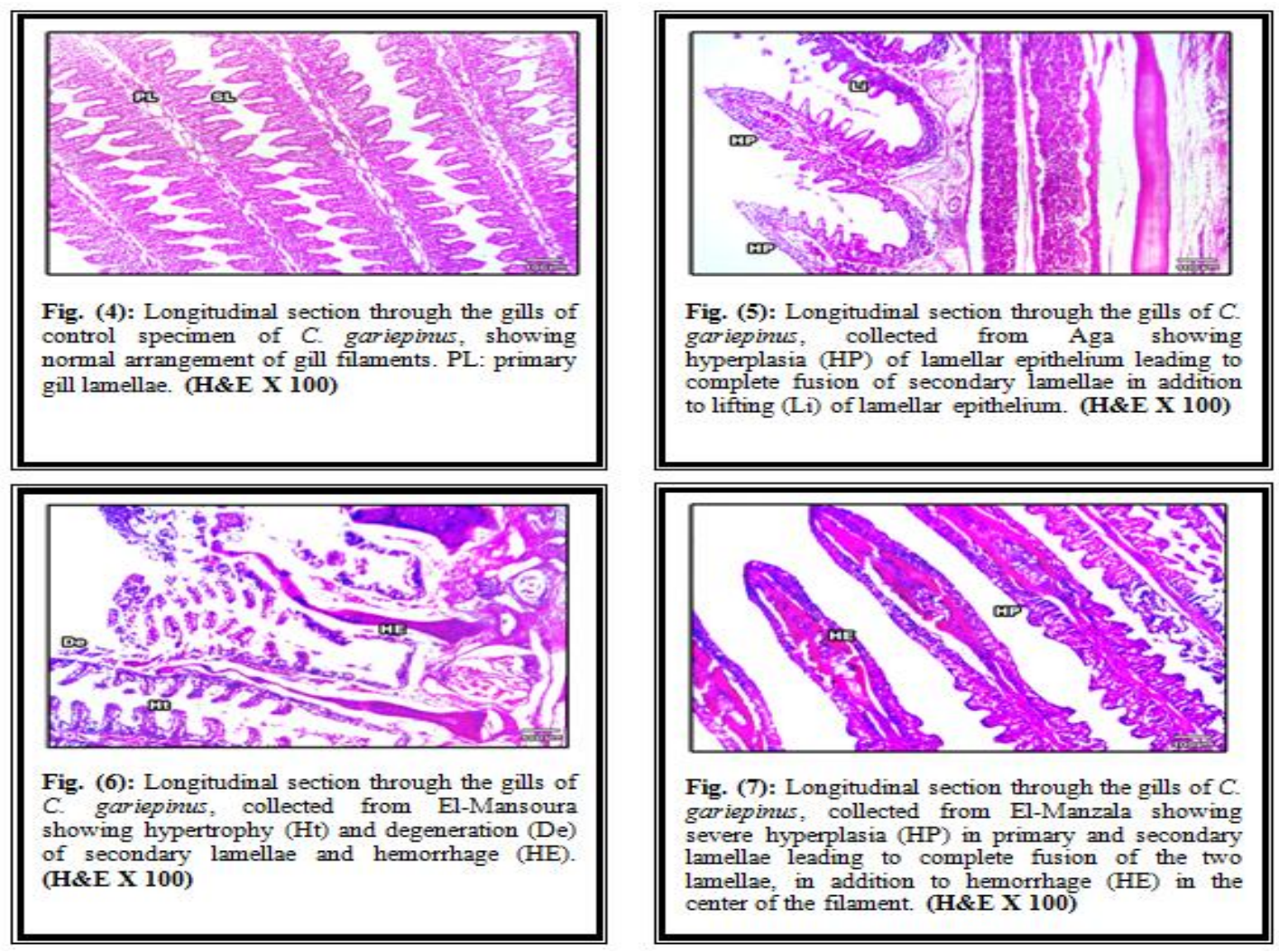
The microscopic photograph structures of liver from control C. gariepinus and specimens were collected form sites 1, 2 and 3 were shown in Figs. 8, 9, 10 and 11, respectively.

The liver is particularly susceptible to damage from many of toxicants. One of the most important functions of liver is to clean pollutants from the blood, so it is considered as an indicator of aquatic environmental pollution [55]. Obviously, it is clearly that liver changes in the $C$. gariepinus fish samples were more severe and in some cases irreparable, reflecting the poor water quality of selected drains. The changes may be related to the direct toxic effects of pollutants on hepatocytes; the present study suggested a strong link between heavy metals and lesions in the liver. Heavy metals might cause liver damage was cited [56]. Similar results after exposure of $C$. gariepinus to lead pollution were discussed [57].

Studies related to the liver of examined fish that showed Hepatocyte vacuolization, hepatic cirrhosis, necrosis, shrinkage, parenchyma degeneration, thrombosis formation in central veins, nuclear pyknosis, dilation and congestion in blood sinusoids, fibrosis or increase of sinusoidal spaces and cloudy swelling or fatty degeneration were observed by different researchers [58] and [55]. Consequently, the histopathological alterations observed in the gills and liver of the studied fish may be attributed to the effects of the agricultural, industrial and sewage wastes.
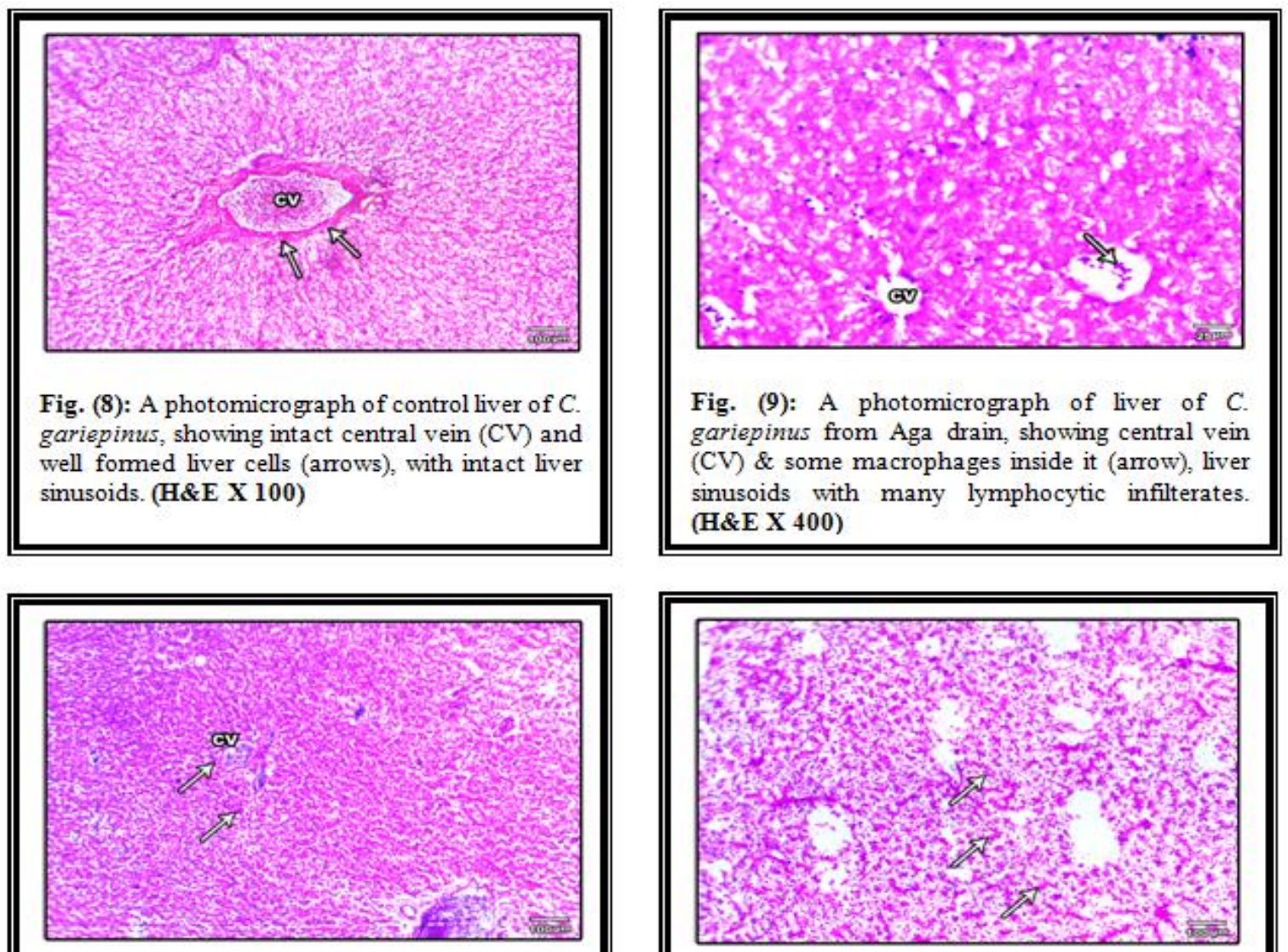

Fig. (10): A photomicrograph in liver of $C$. gariepinus from El-Mansoura drain, showing many lymphocytic infilterates in the central vein (CV) and in between liver cells, also presence of some parasites (arrows). (H\&E X 100)

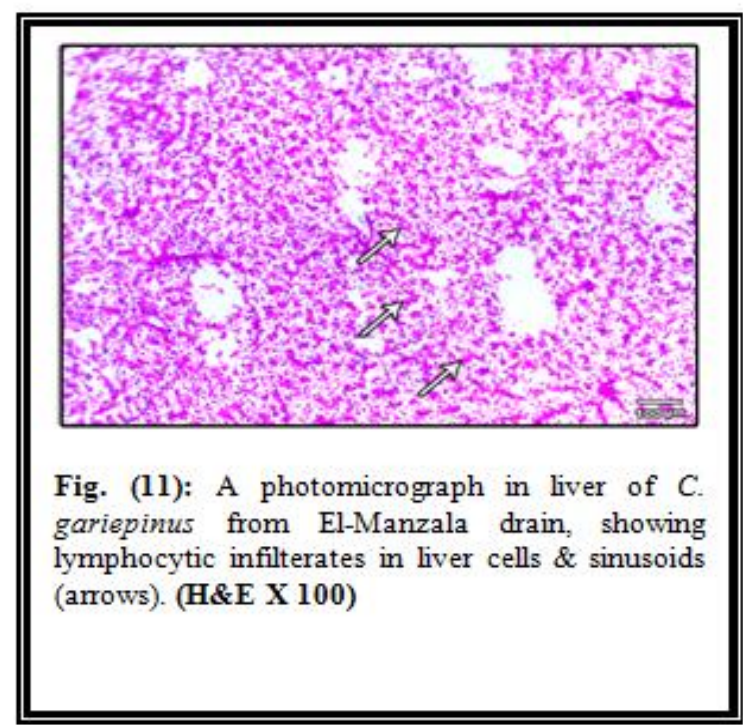

\subsection{Classification of different study sites at different seasons according to water heavy metals concentrations}

The cluster analysis program analyzes the input data of heavy metals values of different investigated sites for different seasons, then grouped them where the high similarity index in heavy metal values between each (site-season) type appears within the same group. Whereas, the differential index heavy metals were divide values for groups (A, B \& C). The application of cluster analysis based on the similarity in heavy metals values of different study sites at different seasons (12 variables) led to the recognition of three groups (Fig. 12). Group 
A comprises four site-season types, sites 1, 2 and 3 in winter and site 1 in autumn. Group B comprises five siteseason types, sites 1,2 and 3 at spring in addition to sites 2 and 3 at autumn. Group C comprises three studyseason types, Aga (sites 1,2 and 3 at summer. These results showed that the seasons were generally having a bright effect on the correlation between different site-season heavy metals values.

\subsection{Classification of different study sites at different seasons according heavy metals accumulated in different organs}

The application of cluster analysis based on the similarity in heavy metals accumulated in different organs of $C$. gariepinus of different study sites at different seasons (12 variables) led to the recognition of four groups A - D (Fig. 13). Group A comprises three study-season types, sites 1 and 2 in spring and site 2 in winter. Group B comprises six study-season types, site 3 during the four seasons in addition to site 1 at autumn and spring. Group C comprises one study-season type, site 1 at summer. Group D comprises two study-season types, site 2 at summer and autumn. It is seem that the accumulation of heavy metals generally did not have a significant difference in all seasons in El-Mansoura (site 3) study drain site.

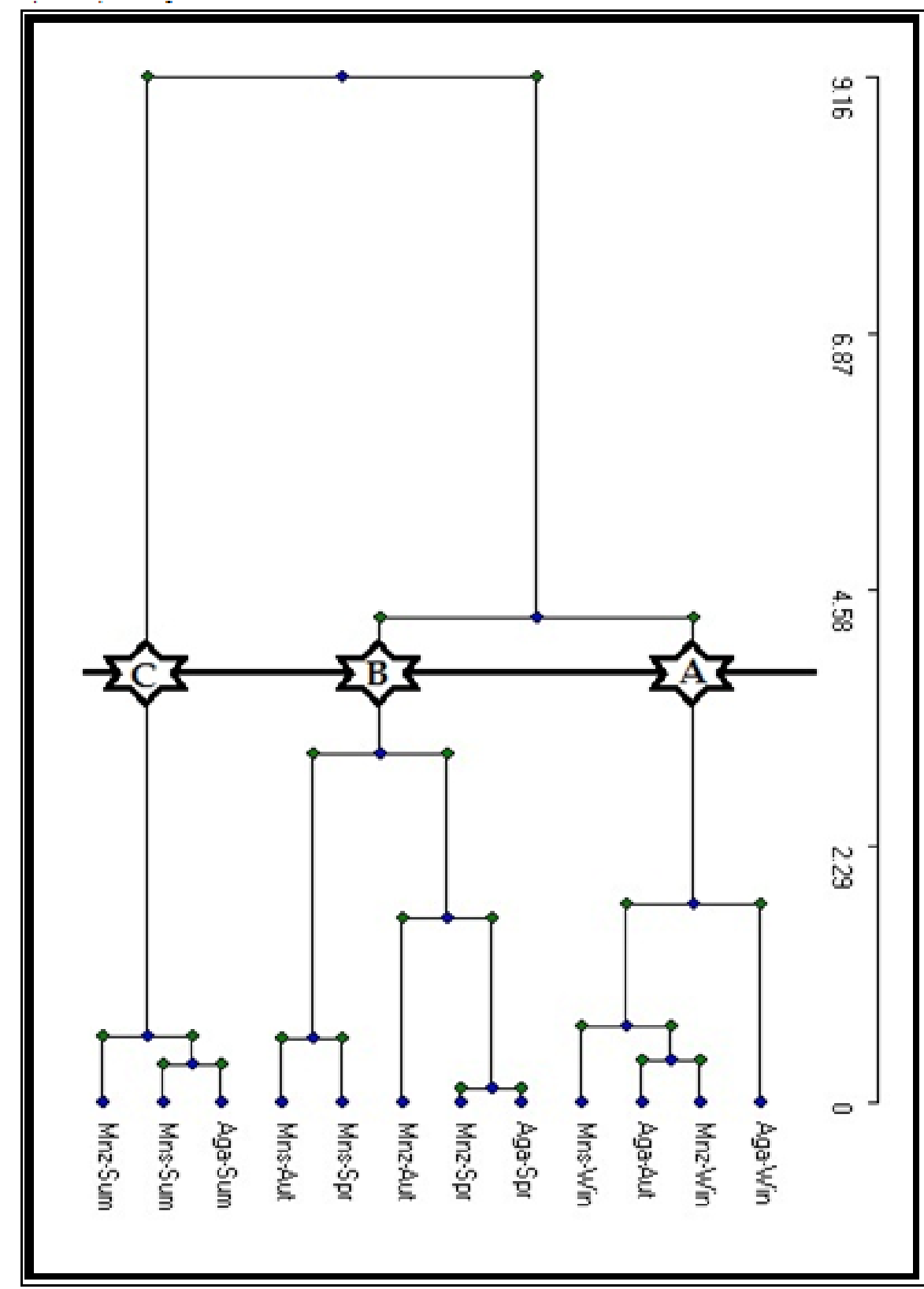

Fig. (12): Cluster analysis of different study sites at different seasons according to heavy metals concentrations. 


\section{Abbreviations:}

\begin{tabular}{|lc}
\hline Aga $=$ Aga & Win $=$ Winter \\
Mnz = El-Manzala & Spr $=$ Spring \\
Mns = El-Mansoura & Sum $=$ Summer \\
& Aut $=$ Autumn
\end{tabular}

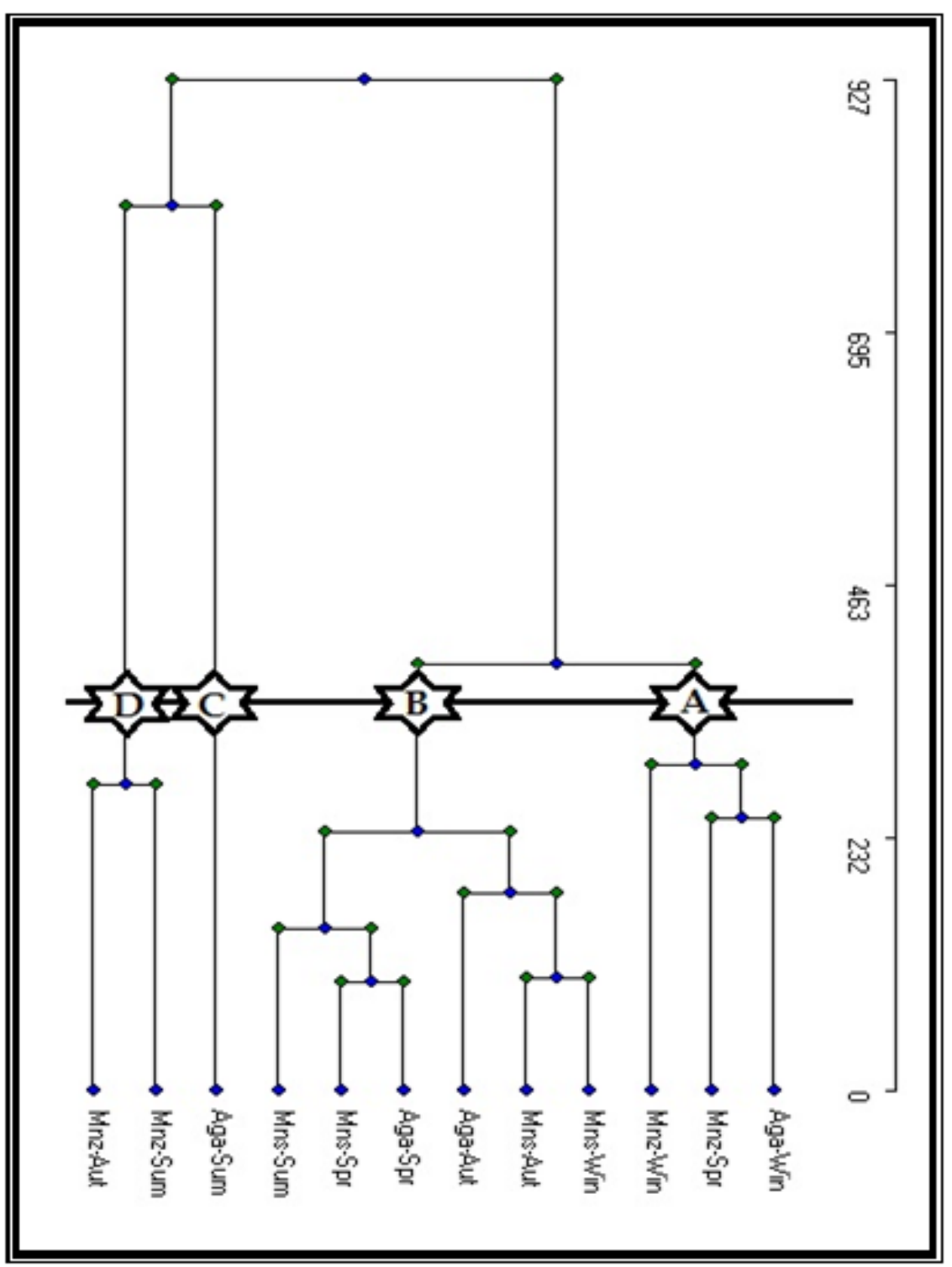

Figure (13): Cluster analysis of different study sites at different seasons according to heavy metals accumulated in different organs of C. gariepinus.

Abbreviations:

\begin{tabular}{|lc|}
\hline Aga $=$ Aga & Win $=$ Winter \\
Mnz = El-Manzala & Spr $=$ Spring \\
Mns = El-Mansoura & Sum = Summer \\
& Aut $=$ Autumn \\
\hline
\end{tabular}




\subsection{Correlation between condition factor of fish and heavy metal values of water}

The Canonical Correspondence Analysis (CCA) program analyzes the input data of all heavy metals concentration values with different condition factor values of $C$. gariepinus for each site seasonally then detect the degree of correlation between each heavy metal in water with condition factor values of fish, whereas the arrow length of each parameter represents the effective degree of this parameter on condition factor value. The correlation between heavy metals and condition factor values was indicated on the ordination diagram produced by (CCA) as shown in Fig. (14). It is clearly that, cadmium, chromium, cobalt, iron, zinc and lead were the most important water heavy metals affecting the condition factor values of $C$. gariepinus in different study sites in all seasons.

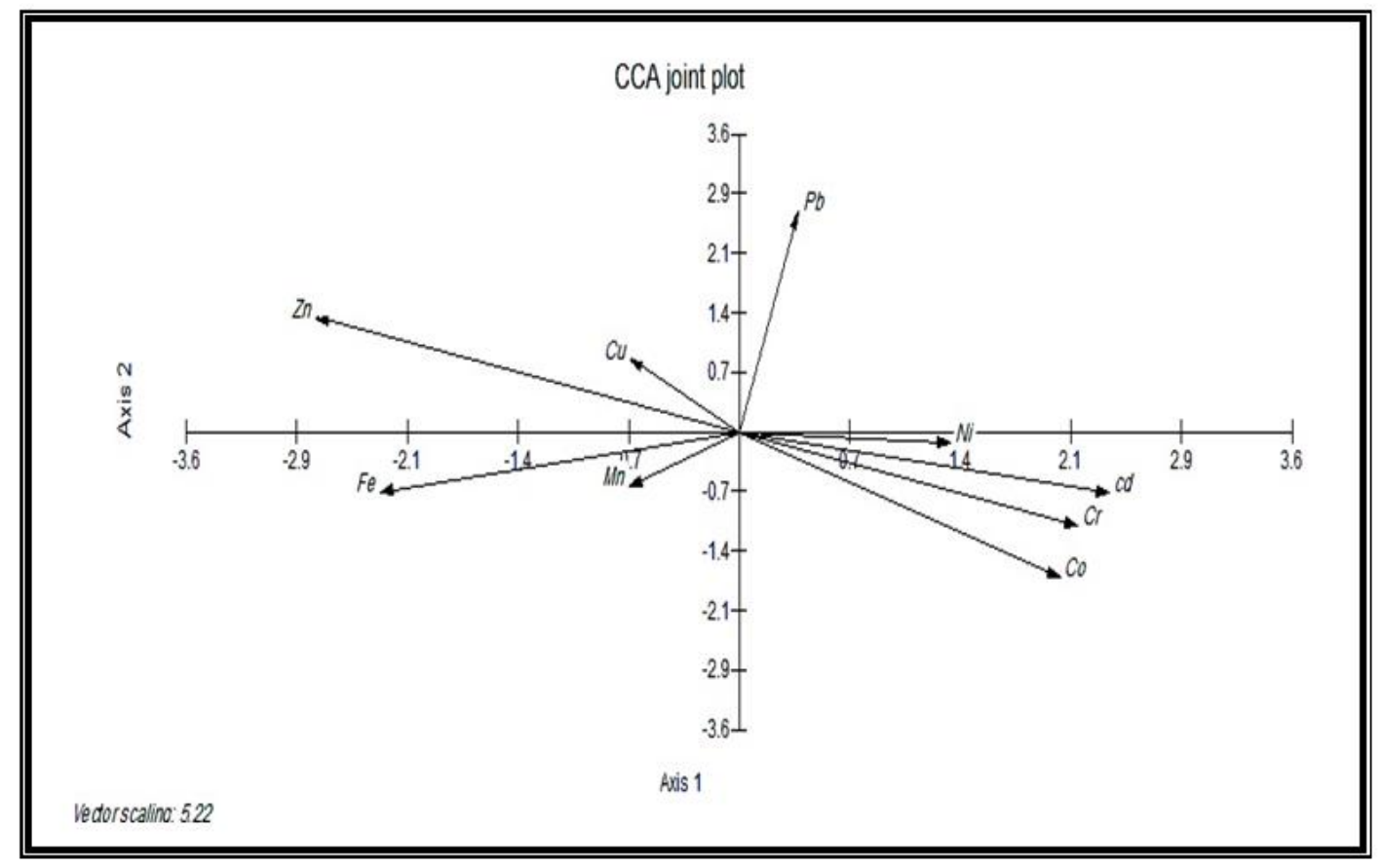

Figure (14): Canonical Corresponding Analysis (CCA) ordination diagram of the factors affecting degree on condition factors of $C$. gariepinus according to the heavy metals (arrows) during the four seasons in the study sites.

\section{Conclusion And Recommendation}

1. Application of cluster analysis based on the similarity in water heavy metals concentrations and heavy metals accumulated in different organs of $C$. gariepinus at different seasons (12 variables) led to the recognition of three and four groups, respectively.

2. The correlation between heavy metal in water samples with condition factor values of fish on the ordination diagram produced by Canonical Correspondence Analysis (CCA) indicated that, cadmium, chromium, cobalt, iron, zinc and lead were the most important water heavy metals affecting the condition factor values of $C$. gariepinus in different study sites at all seasons.

3. Heavy metals are suitable tools to investigate fish ecology. The close relationships of the heavy metals in water to the fish organs have led to the use of heavy metals as biological indicators. Heavy metals conc. in water samples collected form Aga, El-Manzala and El-Mansoura study drain sites could be ranked as follows: $\mathrm{Cu}>\mathrm{Ni}>\mathrm{Mn}>\mathrm{Co}>\mathrm{Cd}>\mathrm{Pb}>\mathrm{Fe}>\mathrm{Cr}>\mathrm{Zn}$.

4. Heavy metals concentrations in fish organs of C. gariepinus were relatively associated with metal content of water in the three drains and detected in the following order: $\mathrm{Fe}>\mathrm{Ni}>\mathrm{Cd}>\mathrm{Pd}>\mathrm{Cr}>\mathrm{Mn}>\mathrm{Zn}>\mathrm{Cu}>$ Co in the investigated parts (organs) was shown to follow the order: liver $>$ gills $>$ muscles.

5. The element levels of fish muscles in this study were over the allowable concentration suggested by WHO (2005) and this will affect negatively to public health.

6. Histopathological alterations observed in the gills and liver of the studied fish may be attributed to the effects of the agricultural, industrial and sewage wastes.

7. Fish represent an important source of animal protein for people in Egypt. Strict control enforced by laws regulation should be applied over polluted industrial wastewater, agricultural drainage water and sewage water debouches into the drains and people ate fish from these polluted drains. 


\section{References}

[1]. M.M.N. Authman, H. H. Abbas, and W. T. Abbas, (2013): Assessment of metal status in drainage canal water and their bioaccumulation in Oreochromis niloticus fish in relation to human health Environmental Monitoring and Assessment, Environmental Monitoring and Assessment, 185(1), 2013, 891-907.

[2]. D.A. El-Badry, Studies on some Diseases in Catfish (Clarias garirpinus) in Dakahlia Governorate, M. Sc. Thesis, Faculty of Science, Mansoura University, Egypt, 2010.

[3]. M.I. Mashaly, Ecological Impacts on Biodiversity of Helminth Parasites on Certain Cichlid and Clariid Fish in Different Localities at River Nile and Lake Manzala in Egypt, Ph.D. Thesis, Faculty of Science, Mansoura University, Egypt. 2015.

[4]. F. Rohde, R. Arndt, D. Lindquist, and J. Parnell, Freshwater fishes of the Carolinas, Virginia, Maryland, and Delaware, Chapel Hill, North Carolina: The University of North Carolina Press, 1994.

[5]. C.R. Kennedy, Freshwater fish parasites and environmental quality: An overview and caution, Parasitologia, 39, 1997, 249-254.

[6]. M.F. Soliman, and M.M. Ibrahim, Monogenean community structure of Oreochromis niloticus in relation to heavy metal pollution and host reproductive cycle, Journal of the Egyptian Society of Parasitology, 42 (1), 2012, 11-42.

[7]. D. Mason, Studies on lipid peroxidation in rat tissues following administration of cadmium chloride, Toxicology, 67, 1991, 303323.

[8]. M.M.N. Authman, M.S. Zaki, E.A. Khallaf, and H.H. Abbas, Use of fish as bio-indicator of the effects of heavy metals pollution, Aquaculture Research \& Development, 6(4), 2015, 1-13.

[9]. H. Ostrowski, C. Vilbur, H. Chou, Y. Pohi, P. Stevens, N. Alfred, M. Roney, L. Fay, and C. Tylenda, (1999): Agency for toxic substances and disease registry's list of hazardous substances. Latent effects carcino-neurotoxicology, and its drevature in humans and animals, Journal of Toxicology and Environmental Health, 15, 1999, 602-644.

[10]. Standard Methods for Examination of Water and water and wastewater, $18^{\text {th }}$ ed. American Public Health Association (Washington, DC, 1992).

[11]. P. Sreedevi, A. Suresh, B. Sivaramakrishna, B. Prabhavathi, and K. Radhakrishnaiah, Bioaccumulation of nickel in the organs of the freshwater fish, Cyprinus carpio, and the freshwater mussel, Lamellidens marginalis, under lethal and sublethal nickel stress, Chemosphere, 24, 1992, 29-36.

[12]. A.F. Fernandes, J.V.F. Cardoso, S.G. Santos, S.M. Monteiro, J. Carrola, P. Matos, and F.F. Fontaínhas, Histopathological changes in liver and gill epithelium of Nile tilapia, Oreochromis niloticus, exposed to waterborne copper, Pesquisa Veterinária Brasileira, 27(3), 2007, 103-109.

[13]. Z.I. Bashir, Z.A. Bortolotto, C.H. Davis, N.A. Berretta, J. Irving, A.J. Seal, J.M. Henley, D.E. Jane, J. C. Watkins, and G.L. Collingridge, Induction of LTP in the hippocampus needs sympatric activation of glutamate metabotropic receptors, Nature, 363, 1993, 347-350.

[14]. A.S. Aboul Ezz, and S.E. Abdel-Razek, Heavy metal accumulation in the Tilapia nilotica L. and in the waters of Lake Manzalah, Egyptian Journal for Applied Science, 6(6), 1991, 37-52.

[15]. M.O. Hill, DECORANA-a FORTRAN Program for Detrended Correspondence Analysis and Reciprocal Averaging (Section of Ecology and Systematic, Cornell Univ., Ithaca, New York, 1979).

[16]. C.J. Ter-Braak, Canonical correspondence analysis: A new eigenvector technique for multivariate direct gradient analysis, Ecology, 67, 1986, 1167-1179

[17]. C.J. Ter-Braak, CANOCO-aFORTRAN Program for Canonical Community Ordination by Partial Detrended Correspondence Analysis, Principal (Component Analysis and Redunancy Analysis (Version 2.1). Agric. Math. Group, Wageninigen, The Netherlands, 1988).

[18]. WHO, Guidelines for Drinking water Ouality (recommendations). (WHO, Geneva, Switerzland, 1985).

[19]. WHO, Guidelines for Drinking Water Quality (World Health Organization, Geneva, Switzerland, 2005)

[20]. T.E. Abdel-Baky, A.E.; Hagras, S.H. Hassan, and M.A. Zyadah, Environmental impact assessment of pollution in lake Manzalah, 1-Distribution of some heavy metals in water and sediment, Journal of the Egyptian-German Society of Zoology, 26 (B), 1998, 2538 .

[21]. S.V. Deore, and S.B. Wagh, Heavy metal induced histopathological alterations in liver of Channa gachua (Ham), Journal of Experimental Sciences, 3(3), 2012, 35-38.

[22]. A.A. Khidr, E.S. Reda, and M.I. Mashaly, Comparative parasitological and ecological studies on monogenean gill parasites infesting some cichlid fish in Manzala and Borollus lakes, north Nile delta, Egypt, Journal of Environmental Sciences, 41 (3), 2012, 427-433.

[23]. FAO, Committee for Inland Fisheries of Africa: Report of the Third Session of the Working Party on Pollution and Fisheries (Accra, Ghana, 25-29 November 1991. FAO Fisheries Report No. 471, FAO, Rome, Italy, 1992).

[24]. USEPA, Quality Criteria for Water. US Environmental Protection Agency (Washington, DC, USA, 1986).

[25]. E.A. Khallaf, M. Galal, and M. Authman, Assessment of heavy metals pollution and their effect on Oreochromis niloticus in aquatic drainage canals, The Egyptian German Society of Zoology, 26 (B), 1998, 39-74.

[26]. H. Agah, M. Leermakers, M. Elskens, S.M.R. Fatemi, and W.Baeyens, Accumulation of trace metals in the muscle and liver tissues of five fish species from the Persian Gulf, Environmental Monitoring and Assessment, 157, 2009, 499-514.

[27]. K.S.A. Said, M.S. Othman, and A.K. Ahmad, The evaluation of water quality and metal concentrations of Titiwangsa Lake, Selangor, Peninsular Malaysia, Pakistan Journal of Biological Sciences, 15, 2012, 459-468.

[28]. C. Kent, Basic Toxicology (John Wiley and Sons, New York, USA, 1998)

[29]. H.H. Saleh, Fish liver as an indicator for aquatic environmental pollution. Bulletin of the National Institute of Oceanography and Fisheries, 8 (1), 1982, 69-79.

[30]. W.H. Clements, D.M. Carlisle, Z.M. Lazorchak, and P.C. Johnson, Heavy metals structure benthic communities in Colorado mountain streams, Ecological Applications, 10, 2000, 626-638.

[31]. B. Sures, Accumulation of heavy metals by intestinal helminths in fish: an overview and perspective, Parasitology, 126, 2003, 5360.

[32]. E.A. Christopher, O. Vincent, I. Grace, E. Rebecca and E. Joseph, Distribution of Heavy Metals in Bones, Gills, Livers and Muscles of (Tilapia) Oreochromis niloticus from Henshaw Town Beach Market in Calabar Nigeria, Pakistan Journal of Nutrition, 8, 2009, 1209-1211.

[33]. Q.Q. Chi, G.W. Zhu, and A. Langdon, Bioaccumulation of heavy metals in fishes from Taihu Lake, China, Journal of Environmental Sciences 19(12), 2007, 1500-1504.

[34]. A. Taweel, M.S. Othman, and A.K. Ahmad, Heavy metals concentration in different organs of tilapia fish (Oreochromis niloticus) from selected areas of Bangi, Selangor, Malaysia, African Journal of Biotechnology, 10(55), 2011, 11562-11566. 
[35]. S.M. Saeed, and I.M. Shaker, Assessment of Heavy Metals Pollution in Water and Sediments and their Effect on Oreochromis niloticus in the Northern Delta Lakes, Egypt, 8th International Symposium on Tilapia in Aquaculture, 2008, 475-490.

[36]. A.M. Ibrahim, M.H. Bahnasawy, E.E. Mansy, and R.I. El-Fayomy, On some heavy metal levels in water, sediment and marine organisms from the Mediterranean coast of Lake Manzalah. Egypt, Egyptian Journal of Aquatic Biology and Fisheries, 4 (4), 2000, 61-81.

[37]. N.A. Ibrahim, and G.O. El-Naggar, Assessment of heavy metals levels in water, sediment and fish at cage fish culture at Damietta Branch of the river Nile, The Journal of Egyptian Academic Society for Environmental Development, 7 (1), 2006, 93-114.

[38]. S. Balasubramanian, P. Bose, R. Jayanti, and S.P. Raj, Bioaccumulation of copper, nickel and cadmium in multicell sewage-fed ponds, Journal of Environmental Biology, 18, 1997, 173-179.

[39]. S. Adhikari, L. Ghosh, B.S. Giri, and S. Ayyappan, Distributions of metals in food web of Kolleru Lake, India, Ecotoxicology and Environmental Safety, 72, 2009, 1242-1248.

[40]. M. Romeo, Y. Siau, Z. Sidoumou, and M. GnassiaBarell, Heavy metals distribution in different fish species from the Mauritania coast, Science of the Total Environment, 232, 1999, 169- 175.

[41]. S. Jent, J.S. Heing, and C.M. Tate, Concentration Distribution and Composition of Selected Trace Metals in Bed Sediment and Fish Tissue in the South Platte River Basin, USA, 1992-1993 (National Water-Quality Assessment (NAWQA) Program Report, 1998).

[42]. M. Jobling, Environmental Biology of Fishes. 1st ed. Printed in Great Britian (Chapman and Hall, London, 1995)

[43]. P. Matthiessen, and A.E. Brafield, Uptake and loss of dissolved zinc by stickle back Gasterosteus aculeatus (L), Journal of Fish Biology, 10, 1977, 399-410.

[44]. F. Guerrin, V. Burgat-Sacaze, and P. Saqui-Sames. Levels of heavy metals and organochlorine pesticides of cyprinid fish reared four years in wastewater treatment pond, The Bulletin of Environmental Contamination and Toxicology, 44, 1990, 461-467.

[45]. S.M. Saeed, and S.F. Sakr, Impact of cage-fish culture in the River Nile on physico-chemical characteristics of water, metals accumulation, histological and some biochemical parameters in fish, Abbassa International Journal for Aquaculture, (1A), 2008, 179-202.

[46]. M. Pacheco, and M.A. Santos, Biotransformation, genotoxic and histopathological effects of environmental contaminants in European eel (Anguilla anguilla L.), Ecotoxicology and Environmental Safety, 53, 2002, 331-347.

[47]. B.M. Alazemi, J.W. Lewis, and E.B. Andrews, Gill damage in the freshwater fish Gnathonemus ptersu (Family: Mormyridae) exposed to selected pollutants: an ultrastructural study, Environmental Technology. 17(3), 1996, 225-238.

[48]. A.G. Yasser, and M.D. Naser, Impact of pollutants on fish collected from different parts Shatt AI-Arab River: a histopathological study, Environmental Monitoring and Assessment, 181, 2011, 175-182.

[49]. F. A. E. S. Mohamed, Histopathological studies on some organs of Oreochromis niloticus, Tilapia zilli and Synodontis schall from EI-Salam canal, Egypt, Egyptian Journal of Aquatic Biology and Fisheries, 7(3), 2003, 99-138.

[50]. I. Kakuta, and S. Murachi, Physiological response of carp, Cyprinus carpio, exposed to raw sewage containing fish processing wastewater, Environmental Toxicology and Water Quality, 12(1), 1997 1-9.

[51]. K.B. Olurin, E.A.A. Olojo, G.O. Mbaka, and A.T. Akindele, Histopathological responses of the gill and liver tissues of Clarias gariepinus fingerlings to the herbicide, glyphosate, Journal of Biotechnology, 5:(24), 2006, 2480-2487.

[52]. M.N. Fernandes, and A.F. Mazon, Environmental pollution and fish gill morphology. In: Val AL, Kapoor BG (eds:). Fish adaptations, Science Publishers, Enfield, 2003, 203-231.

[53]. M.M.P. Camargo, C.B.R. Martinez, (2007) Histopathology of gills, kidney and liver of a neotropical fish caged in an urban stream, Neotropical Ichthyology, 5(3), 2007, 327-336.

[54]. V. Poleksic, V. Mitrovic-Tutundzic, Fish gills as a monitor of sublethal and chronic effects of pollution, In: Muller R., Lloyd R (Eds.), Sublethal and chronic toxic effects of pollutants on freshwater fish, (Blackwell Scientific Publications Ltd., Oxford, 1994)

[55]. H.M. Soufy, E. Soliman, E.I.Manakhly, and A. Gaafa, Some biochemical and pathological investigations on monosex Tilapia following, The Bulletin of Environmental Contamination and Toxicology, 43, 2007, 315- 320.

[56]. E.M.B. Sorensen, Metal poisoning in fish: Environmental and life sciences Associates (CRC Press Inc., Austin, Texas, Boston, 1991).

[57]. S.M. Aly, M.S. Zaki and H.M. El-Genaidy, Pathological, biochemical, haematological and hormonal changes in catfish (Clarias gariepinus) exposed to lead pollution Journal of the Egyptian Veterinary Medical Association, 63(1), 2003, 331-342.

[58]. E.A.A. Olojo, K.B. Olurin, G. Mbaka and A.D. Oluwemimo, Histopathology of the gill and liver tissues of the African catfish, Clarias gariepinus exposed to lead, African Journal of Biotechnology, 4(1), 2005, 117-122. 